\title{
Lipid requirement of bay snook (Petenia splendida Günther, 1862) juveniles
}

\author{
Uriel Rodríguez-Estrada ${ }^{1,5}$, Otilio Méndez-Marín ${ }^{1}$, Alfredo Pérez-Morales ${ }^{2}$, Rafael Martínez-García ${ }^{1}$ \\ Emyr Peña-Marín ${ }^{1,5}$, Roberto Civera-Cerecedo ${ }^{3}$, Ernesto Goytortua-Bores, E. ${ }^{3}$ \\ Rosario Martínez-Yáñez ${ }^{4}$ \& Carlos A. Alvarez-González ${ }^{1}$ \\ ${ }^{1}$ Laboratory of Tropical Aquaculture, Academic Division of Biological Sciences (DACBiol) \\ Universidad Juárez Autónoma de Tabasco, Villahermosa, Tabasco, México \\ ${ }^{2}$ Centro Universitario de Investigaciones Oceanológicas, Universidad de Colima \\ Manzanillo, Colima, México \\ ${ }^{3}$ Laboratory of Aquatic Nutrition, Centro de Investigación Biológica del Noroeste (CIBNOR) \\ La Paz, B.C.S., México \\ ${ }^{4}$ Laboratorio de Acuicultura, Departamento de Veterinaria y Zootecnia, División de Ciencias de la Vida \\ Universidad de Guanajuato, Irapuato, Guanajuato, México \\ ${ }^{5}$ Cátedra, Consejo Nacional de Ciencia y Tecnología (CONACYT), Ciudad de México, México \\ Corresponding author: Carlos A. Alvarez-González (alvarez_alfonso@hotmail.com)
}

\begin{abstract}
This research study is focused on the lipid requirements of Petenia splendida $(0.65 \pm 0.19 \mathrm{~g})$ juveniles. Fish were fed with trout commercial diet (Silver Cup $\mathrm{Cu}^{\mathrm{TM}}-45 \%$ protein and $16 \%$ lipids), as control diet - CD (which is usually used to feed this species at commercial scale), and four isoproteic (45\% crude protein) diet formulated with different lipid levels $(5,10,15$ and 20\%). Diets were administered for 60 days by triplicate per treatment. Our results showed that fish fed with 10, 15 and 20\% lipid levels were significantly higher $(P<$ $0.05)$ in average weight and total length. Same treatments were significantly lower $(P<0.05)$ in terms of FCR compared to those shown in 5\% and CD. However, fish fed $20 \%$ lipid level, showed a significant decrease in WG and a significant $(P<0.05)$ increase in FCR compared to those shown in $15 \%$ lipid level. Fish fed with $15 \%$ showed the highest weight gain and the lowest FCR compared with the rest of the treatments. Lipid efficiency ratio (LER) showed significant $(P<0.05)$ differences among experimental groups. Compared to other diets containing lipid levels $(5,10$, and $20 \%)$ fish fed $15 \%$ diet recorded the lowest protein and lipid content in whole body. Additionally, based on second order polynomial regression analysis of WG, it was demonstrated that $16.2 \%$ lipid provides an optimal growth for P. splendida.
\end{abstract}

Keywords: Petenia splendida; bay snook; diet; lipid requirement; aquaculture

\section{INTRODUCTION}

Current global aquaculture development is based on species diversification (Ahmed \& Thompson, 2019). The worldwide freshwater fish farming industry is focused in exotic species such as Nile tilapia (Oreochromis niloticus), salmon (Salmo salar), and common carp (Cyprinus carpio) among others, which have achieved a steady production and a highly profitable economic return (Olaussen, 2018; Kim et al., 2019). However, traditionally exploited species have faced aggressive international markets and high uncer- tainty (Anderson et al., 2018). Furthermore, epizootic diseases, dramatic changes in environmental conditions, and massive pollution endanger the sustainability of current farmed species (Goldburg \& Naylor, 2005; Shariff, 2007; Brander et al., 2017). Therefore, it is essential to reduce dependency/pressure in exploited animals utilizing culturing new species with high potential for aquaculture (namely: aquaculture diversification) (Bush et al., 2019).

Ichthyological biodiversity of Mexico possesses a significant number of native species with high potential to be exploited for aquaculture (Hulsey et al., 2004;

Corresponding editor: Yassir Torres 
Chávez-López et al., 2005; Abdo de la Parra et al., 2015; Castillo-Torres et al., 2017). Unfortunately, little attention has been focused on native species (Ross \& Beveridge, 1995). Mexican cichlids have attracted attention as candidates for aquaculture (Chávez de Martínez, 1990; Deveze-Murillo et al., 2004; Hernández et al., 2014; Dávila-Camacho et al., 2018).

Bay snook (Petenia splendida Günther, 1862), locally known as "tenhuayaca" (Pérez-Sánchez \& Páramo-Delgadillo, 2008) is a highly valued native cichlid for human consumption, inhabiting freshwater bodies (sandy and moody bottoms) from southeast of Mexico (Tabasco, Chiapas, Campeche, \& Quintana Roo states) down to Central America. It represents significant ecological importance and economic value (locally and regionally) for aquaculture (Méndez et al., 2011). Petenia splendida is a carnivorous fish (Álvarez-González et al., 2008) that can be produced all year long. Experimental and semi-industrial production of $P$. splendida started 20 years ago at Universidada Juárez Autónoma de Tabasco (UJAT), Academic Division of Biological Sciences (DACBiol) southeast of Mexico, where production continues until now. This species' reproduction and growth have been conducted at experimental and pilot-commercial systems such as ponds (earthen \& concrete) and geomembranes (Instituto Nacional de Pesca, 2019) semi-intensive and intensive levels. As in other cichlid species, such as $O$. niloticus, only male stocks are used for regular culture to obtain the fastest growth rates and control reproduction at early stages. In the south of Mexico, at commercial scale, $P$. splendida is growing up in all-male stocks to obtain efficient productivity in aquaculture systems. Sex reversal of tenguayaca is obtained using 17 $\alpha$-methyl-testosterone (MT) (Instituto Nacional de Pesca, 2019).

Petenia splendida has been subjected to several studies related to biology and physiology (AlvarezGonzález et al., 2008; Jiménez-Martínez et al., 2009), taxonomy and ecology (Méndez et al., 2011), and aquaculture technology (Pérez-Sánchez \& PáramoDelgadillo, 2008; Jiménez-Martínez et al., 2009; VidalLópez et al., 2009) including embryonic development, optimal light, and temperature conditions, breeders management, larviculture, and stocking densities. Research in nutrition and feeding of $P$. splendida is not well developed. Therefore, bay snook is currently fed with rainbow trout (Oncorhynchus mykiss) diet obtaining acceptable parameters (Instituto Nacional de Pesca, 2019). However, an experimental formulation for this species (based in in vitro - $\mathrm{pH}$ stat- assays) developed at UJAT - DACBiol has obtained better results (Alvarez-González et al., 2008). However, it is necessary to optimize $P$. splendida diet currently used in order to obtain improved outcomes. The efficiency of aquafeeds is achieved with balanced formulations with a proper nutrient level for each organism. It is important to know nutrient requirements (Sales \& Janssens, 2003) and adequate feed management (Tacon \& Foster, 2003) of each fish species to obtain desired outcomes. Lipid is one of the most fundamental nutrients providing an optimal growth performance of fish (Hua et al., 2019). These nutrients are the primary source of energy, have a structural function in cellular membranes, promote the protection of cells, recognize external elements, and absorbing liposoluble vitamins, among other functions (Ayisi et al., 2018). Lipid requirements studies have been reported in many species, spotted rose snapper Lutjanus guttatus (Abdo de la Parra et al., 2010), Murray cod Maccullochella peelii (Turchini et al., 2011), grass carp Ctenopharyngodon idella (Jin et al., 2013), and Florida pompano Trachinotus carolinus (Rombenso et al., 2016), among many others. However, knowledge of lipid requirement in certain species such as $P$. splendida is null. Thus, this research was aimed to assess the optimal lipid requirement of $P$. splendida juveniles, a highly valued native species of Mexico with a strong potential for aquaculture.

\section{MATERIALS AND METHODS}

\section{Fish procurement}

Broodstock of Petenia splendida (275 g average weight) was procured at facilities of the Tropical Aquaculture Laboratory of the Academic Division of Biological Sciences (DACBiol) at Universidad Juárez Autónoma de Tabasco (UJAT). Breeders were kept in circular tanks $(2,000 \mathrm{~L}, 2 \mathrm{~m}$ diameter, $0.65 \mathrm{~m}$ depth of an open system with a $10 \%$ of daily water exchange. The average temperature was $30 \pm 0.5^{\circ} \mathrm{C}$, and the $\mathrm{pH}$ was controlled at 7. Broodstock was fed three times per day at $10 \%$ of average body weight. Each tank was equipped with $6 \mathrm{PVC}$ shelters functioning as nets. The sexual proportion was $1: 2$ (one $\delta$ : two + ). Once spawning was achieved, larvae were collected $(4,500$ fish) and stocked in $100 \mathrm{~L}$ tanks $\left(27 \pm 1^{\circ} \mathrm{C} /\right.$ constant aeration) for six days until the yolk sac was absorbed and external feeding was initiated. Larvae were fed with Artemia spp. nauplii. To obtain sexual reversion, Artemia was enriched with $20 \mathrm{mg}$ of $17 \alpha-$ methyltestosterone (MT). Artemia spp. nauplii were procured following standard methods described by Vidal-López et al. (2009). After hatching (24 h), Artemia nauplii were enriched with MT for $2 \mathrm{~h}$. MT enriched Artemia, was administered (at satiation level) to $P$. splendida larvae, four times a day (09:00, 12:00. 15:00 and 17:00 h) for 15 days. After this live-feed 
period, to complete the masculinization process, fish was fed with commercial feed (Silver Cup ${ }^{\circledR}$, Salt Lake, USA, $52 \%$ protein and $14 \%$ lipid) supplemented with $60 \mathrm{mg} \mathrm{kg}^{-1}$ of $17 \alpha$-MT for 30 days.

\section{Experimental diets}

As noted above, the overall aim of this study was to simulate commercially relevant culture conditions for bay snook. Consequently, the commercial diet Silver Cup $^{\mathrm{TM}}$ (45\% protein and 16\% lipids), commonly used to feed this species at commercial scale was a valid control diet. Four diets were isoproteic designed to contain 5, 10, 15, and 20\% of lipid (Table 1). According to our laboratory working procedures, all raw materials used for diet preparation are subject to proximal composition analysis. Raw materials used in this research are themselves inferred from the analysis of the raw materials validated in numerous previous studies from our group (Uscanga-Martínez et al., 2012; Montoya-Martínez et al., 2016; Trejo-Escamilla et al., 2016). Casein was used as the main protein source, because of its valuable protein source in purified test diets in fish and its availability. Previous studies have used casein as the sole protein source in rainbow trout, Oncorhynchus mykiss (Morales et al., 1994). Furthermore, casein is the protein source used in the original formulation prepared for bay snook, $P$. splendida, achieving optimal performance in this species fed with formulated diets with casein.

Fishmeal, sorghum flour, and casein were sieved $(500 \mu \mathrm{m})$. Mineral premix, vitamin C, lysine, Lmethionine, betaine, and gelatin were homogenized (15 min) in an industrial mixer (Bathamex, 178716, CDMX, Mexico). Soybean lecithin and fish oil were manually mixed until obtaining an orange color mixture. Other ingredients were added to this blend and mixed during $15 \mathrm{~min}$ with distilled water until obtaining a homogeneous mass. This mass was processed in a meat grinder (Torrey, M-22RI, 130 Monterrey, N.L., Mexico) to obtain the pellets. Pellets were manually cut and sieved to obtain different feed sizes: 300,500 , and $1,000 \mu \mathrm{m}$, to be used for different fish sizes during all experimental periods. Pellets were oven-dried (Coriat, HC-131 35-D, CDMX, Mexico) for $12 \mathrm{~h}$ at $35^{\circ} \mathrm{C}$.

\section{Feeding trial}

The feeding trial was conducted at the wet lab of the Laboratory of Tropical Aquaculture of DACBiol UJAT. At the beginning of the experiment, 30 fish $(0.65 \pm 0.19 \mathrm{~g})$ were stocked for the experiment in a blue plastic tank (100 L each) set in a RAS (recirculating aquaculture system) equipped with a sedimenter, sand and biological filters (STA-RITE, S166T, Delavan,
Table 1. Experimental diets formulation $\left(\mathrm{g} \mathrm{kg}^{-1}\right)$ for Petenia splendida juveniles, containing four levels of lipid

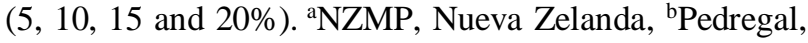
Toluca, Edo. Mex. México, 'Sigma-Aldrich \# catálogo F8020, 'Pronat Ultra. Mérida, Yucatán, México, ${ }^{\text {eSigma- }}$ Aldrich \# catalogue C4888, ${ }^{\mathrm{f}}$ Research Organics \# inventory $9086,{ }^{g} \mathrm{IU} \mathrm{kg}{ }^{-1}$ or $\mathrm{g} \mathrm{kg}^{-1}$ of premix: vitamin $\mathrm{A}$, 1.0 MIU; vitamin D3, 0.5 MIU; vitamin E, 0.04 MIU; vitamin $\mathrm{K}, 3.4 \mathrm{~g}$; vitamin B1, $4 \mathrm{~g}$; vitamin B2, $6 \mathrm{~g}$; vitamin B5, $10 \mathrm{~g}$; vitamin B6, $2 \mathrm{~g}$; vitamin B9, $1.6 \mathrm{~g}$; vitamin B12, $0.004 \mathrm{~g}$; niacin, $40 \mathrm{~g}$; biotin, $0.1 \mathrm{~g}$; vitamin $\mathrm{C}, 100 \mathrm{~g}$; choline, $200 \mathrm{~g}$; inositol, $50 \mathrm{~g}$, hper g mixture: $\mathrm{mg}$; $\mathrm{Cu}: 8.3$ mg; Mn: $67 \mathrm{mg}$; Co: $1.7 \mathrm{mg}$; y: 1.7; Zn: $200 \mathrm{mg}$, ${ }^{\text {Research }}$ Organics \# catalogue 0122M. ${ }^{\text {ROVVIMIX }}{ }^{\circledR}$ C-EC (Roche), ${ }^{k}$ Research Organics \# catalogue B-2629. DM: Dry matter.

\begin{tabular}{|c|c|c|c|c|}
\hline \multirow{2}{*}{ Ingredients } & \multicolumn{4}{|c|}{ Lipids (\%) } \\
\hline & 5 & 10 & 15 & 20 \\
\hline Casein $^{\mathrm{a}}$ & 44.57 & 45.13 & 45.69 & 46.25 \\
\hline Sorghum flour ${ }^{\mathrm{b}}$ & 38.00 & 32.15 & 26.30 & 20.39 \\
\hline Fish oil ${ }^{c}$ & 2.02 & 5.81 & 9.60 & 12.95 \\
\hline Soy lecithin ${ }^{\mathrm{d}}$ & 1.00 & 2.50 & 4.00 & 6.00 \\
\hline Fish meal $^{\mathrm{b}}$ & 10.00 & 10.00 & 10.00 & 10.00 \\
\hline Carboxymethyl cellulose $\mathrm{e}^{\mathrm{e}}$ & 2.96 & 2.96 & 2.96 & 2.96 \\
\hline Lysine $^{f}$ & 0.50 & 0.50 & 0.50 & 0.50 \\
\hline Vitamin premix ${ }^{\mathrm{g}}$ & 0.25 & 0.25 & 0.25 & 0.25 \\
\hline Mineral premix ${ }^{\mathrm{h}}$ & 0.15 & 0.15 & 0.15 & 0.15 \\
\hline L-methionine ${ }^{\mathrm{i}}$ & 0.50 & 0.50 & 0.50 & 0.50 \\
\hline Vitamin $C^{j}$ & 0.05 & 0.05 & 0.05 & 0.05 \\
\hline Betain $^{\mathrm{k}}$ & 0.004 & 0.004 & 0.004 & 0.004 \\
\hline \multicolumn{5}{|c|}{ Proximate composition $\left({\left.\mathrm{g} 100 \mathrm{~g} \mathrm{DM}^{-1}\right)}\right.$} \\
\hline Crude protein & 45.0 & 45.0 & 45.0 & 45.0 \\
\hline Ether extract & 5.0 & 10.0 & 15.0 & 20.0 \\
\hline Crude fiber & 3.6 & 3.5 & 3.4 & 3.3 \\
\hline Ash & 3.6 & 3.4 & 3.3 & 3.3 \\
\hline Nitrogen-free extract & 43.0 & 38.1 & 33.3 & 28.4 \\
\hline Gross energy (kcal g) & 3970 & 4224 & 4482 & 4732 \\
\hline
\end{tabular}

WI, USA). Water was propelled by a $1 / 4 \mathrm{HP}$ submersible pump (Jacuzzi Star-Rite, JWPA5D-230a Delavan, WI, USA) located in a reservoir $(1,500 \mathrm{~L})$. The temperature was controlled by two titanium thermostats (PSA, R 9CE271, Delaware, USA). Water temperature (26.3 \pm $0.51^{\circ} \mathrm{C}$ ) was measured with a Brannan ${ }^{\circledR}$ thermometer (Salt Lake, Utah, USA). pH (7.1 \pm 0.2$)$ was estimated with a Hanna Instruments pH meter (HI 98311, Rhode Island, USA). Dissolved oxygen $\left(5.3 \pm 0.6 \mathrm{mg} \mathrm{mL}^{-1}\right)$ was monitored with a YSI ${ }^{\circledR} 55$ oximeter (Springer, CA, USA). All parameters were daily measured in each experimental tank. Experimental diets were administered to triplicate tanks for 60 days. Daily feed consumption was measured using an analytical balance (Ohaus, NJ, USA, precision $0.0001 \mathrm{~g}$ ). Initially, $10 \%$ of the total biomass was administered per tank. According to the daily consumption of feed, the amount was adjusted to keep a satiation level. During this period, fish were fed three times per day (09:00, 13:00 and 17:00 h). 


\section{Samplings}

Total length and weight were assessed every 15 days by a biometry sampling. Fish were weighted with a precision balance 0.0001g (Ohaus, Atlantic City, NJ, USA). Before weighting each fish, excess of water was removed with absorbent paper. Total length was measured with a digital Vernier with a precision of 0.1 mm (Electronic Digital, 140677256, Madrid, Spain).

\section{Chemical analysis}

A proximal composition (crude protein, crude lipid, fiber, nitrogen-free extract, ash, and gross energy) of diets and whole body was conducted according to the Association of Official Analytical Chemistry (AOAC, 1995). Briefly, samples were dried to a constant weight at $105^{\circ} \mathrm{C}$ for $2 \mathrm{~h}$ to determine their dry matter content. A muffle furnace determined ash at $550^{\circ} \mathrm{C}$ for $3 \mathrm{~h}$. Lipid content was calculated gravimetrically after hot extraction using Soxhlet equipment and petroleum ether. Total crude protein was analyzed by the Kjeldahl method $(\mathrm{N} \times 6.25)$ after acid digestion, distillation, and titration. Fiber content was determined through acid digestion of defatted samples with $\mathrm{H}_{2} \mathrm{SO}_{4}(0.225 \mathrm{~N})$, followed by alkaline digestion with $\mathrm{NaOH}(0.313 \mathrm{~N})$. The residue was dried in an oven at $105^{\circ} \mathrm{C}$ until constant weight and burned in a furnace at $550^{\circ} \mathrm{C}$ for $30 \mathrm{~min}$. Nitrogen free extract was calculated following standard formula $(\mathrm{NFE}=\mathrm{DM}-(\% \mathrm{EE}+\% \mathrm{CP}+\% \mathrm{ash}+\% \mathrm{CF})$, where $\mathrm{DM}=$ dry matter; $\mathrm{E}=$ ether extract; $\mathrm{CP}=$ crude protein; $\mathrm{CF}=$ crude fiber). Gross energy (for the whole body) content was calculated by a calorimeter (C2000, IKA). The analysis was conducted at Northwest Biological Research Center (CIBNOR), La Paz, Baja California Sur, Mexico.

\section{Calculations}

The following parameters were determined: weight gain: WG $(\%)=100 \times(\mathrm{FBW}-\mathrm{IBW}) / \mathrm{IBW}$; feed conversion ratio: $\mathrm{FCR}=$ weight of consumed feed / weight gain; daily feed intake: FI = (consumed feed) number of fish / number of days; daily lipid intake: DLI $(\mathrm{g}$ fish $)=$ consumed lipid $/$ time $(\mathrm{d}) \times$ (final fish number); lipid efficiency rate: $L E R=$ fish weight gain / lipid weight in feed; condition factor: $\mathrm{K}=$ (final average weight / final total length) $\times 100$; survival: $\mathrm{S}=$ (initial number of fish / final number of fish ) $\times 100$. $\operatorname{NFE}(\%)=100-($ protein $\%+$ lipid $\%+$ fibre $\%+$ ash $\%)$. Gross energy of experimental diets was calculated from the caloric content of protein, lipid and carbohydrates.

\section{Statistical analysis}

In order to determine the normality and homogeneity of obtained data, Kolmogorov-Smirnov and Levene tests were used. Differences between replicates were identified by ANOVA and later by the Tukey test.
Regarding growth, whole body, and feed proximal composition, non-parametric tests (Kruskal-Wallis and later on Nemenyi) were applied. A second-order polynomial regression analysis $(\mathrm{k}=2)$ with an interaction of a matrix analysis was applied $\left(y=y^{0}+a x\right.$ $+b^{2}$ ) to average weight concerning lipid content of diets. This model was obtained by a model structure built from regression coefficients to obtain a quadratic expression. Data were processed with Statistica 7.0, and the significance level for all tests was 0.05 .

\section{RESULTS}

Proximal composition of diets did not show differences regarding crude protein, ether extract, crude fiber, ash, and nitrogen free extract. However, gross energy increased as dietary lipid inclusion increased in diets.

The growth of all experimental groups of Petenia splendida's juveniles showed a steady and similar trend in the first 30 days of the experimental period. However, after this period, significant differences $(P<$ 0.05 ) in weight gain and total length were recorded (Figs. 1a-b). A second-order polynomial regression analysis showed that an optimal level of lipids for $P$. splendida juveniles is $16.2 \%\left(\mathrm{R}^{2}=0.80\right)$ for estimated parameters of the model (Fig. 2).

The full body composition analysis showed that fiber, ash, nitrogen-free extract, and gross energy of the whole body did not show significant $(P>0.05)$ differences among experimental groups. In contrast, protein content in the whole body of 5\% group was significantly higher $(P<0.05)$ compared to that shown in control diet (CD) and 15\% experimental groups. There were not significant $(P>0.05)$ differences among protein content of 5,10, and $20 \%$ experimental groups. Similarly, lipid content in the whole body did not show significant $(P>0.05)$ differences between CD experimental group and fish consuming diets containing any supplementation levels of lipid. Lipid content in the whole body of fish fed 10 and $20 \%$ diets recorded higher $(P<0.05)$ values compared to those shown in 5 and $15 \%$ diets (Table 2). Feed intake (FI), daily lipid intake (DLI), condition factor $(\mathrm{K})$, and survival did not show significant $(P>0.05)$ differences among experimental groups. Compared to the $\mathrm{CD}$ group, fish fed experimental diets containing any level of lipid $(5,10,15$, and $20 \%)$ resulted in a significantly higher $(P<0.05)$ weight gain (WG). Among lipid supplemented experimental diets, $15 \%$ showed the highest $(P<0.05)$ weight. Feed conversion ratio (FCR) showed a significantly higher $(P<0.05)$ value in $\mathrm{CD}$ compared to that shown in the rest of the experimental diets. Among lipid supplemented experimental diets, $15 \%$ showed the lowest $(P<0.05)$ FCR. Lipid efficien- 

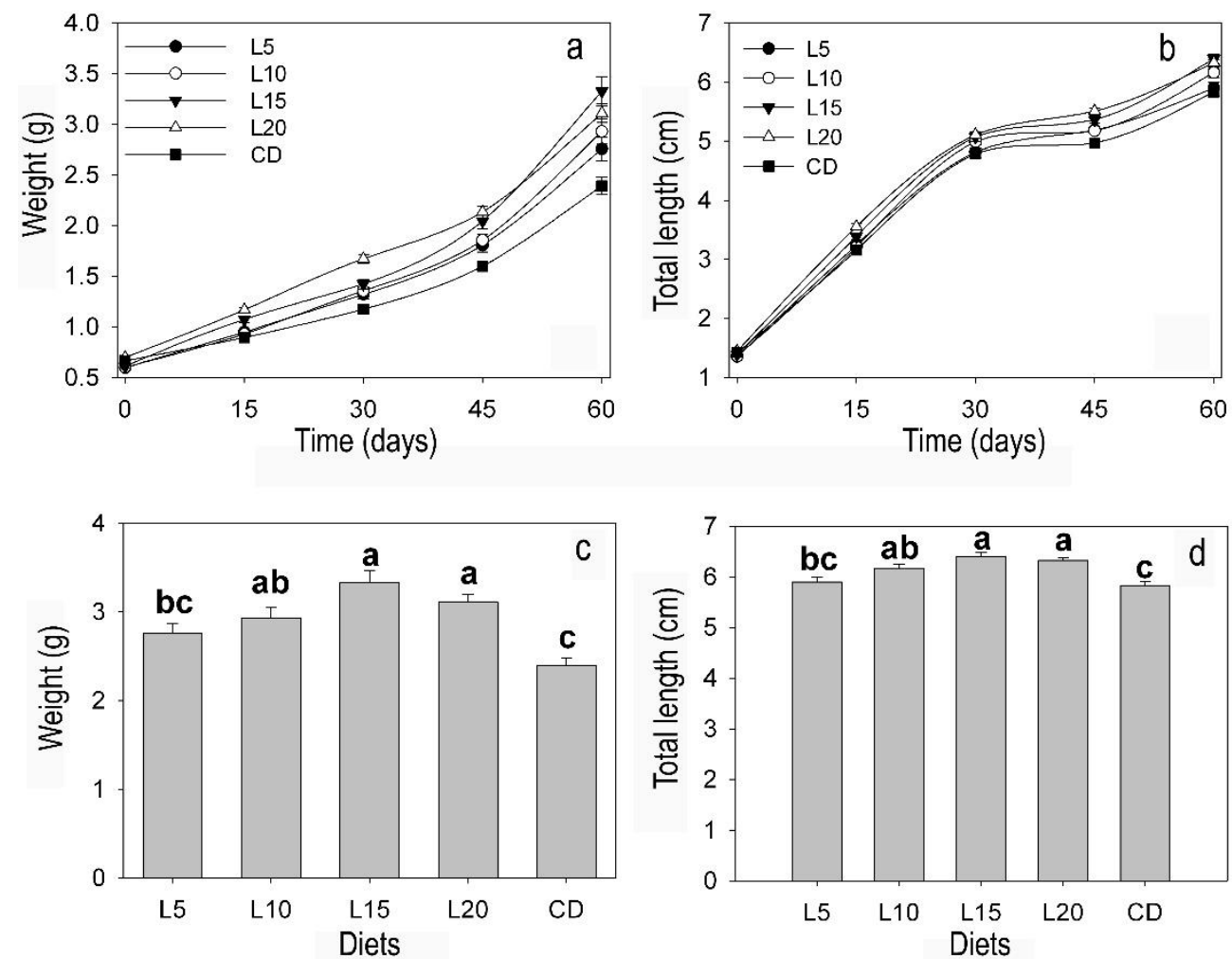

Figure 1. a) Weight-related to time, b) total length related to time, c) the average weight per experimental group, and d) total length average per experimental treatment, of Petenia splendida juveniles fed four diets formulated with different lipid levels $(5,10,15$ and 20\%).

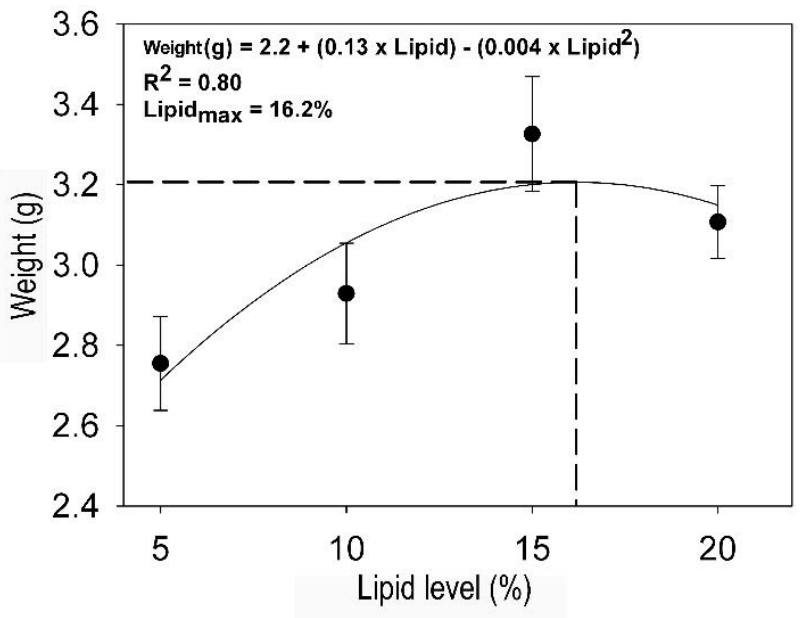

Figure 2. The second-order polynomial model concerning weight (mean \pm standard deviation, g) of Petenia splendida juveniles fed four diets formulated with different lipid levels $(5,10,15$, and $20 \%)$ for 60 days.

cy ratio (LER) was significantly $(P<0.05)$ higher in 5 and $10 \%$ compared to that shown in CD, 15 and $20 \%$. The highest $(P<0.05)$ LER was shown in 5\% (Table $3)$.

\section{DISCUSSION}

Determination of nutritional requirements is a prerequisite in the formulation of feeds for newly cultured fish species (Toledo-Solís et al., 2020). Ingredients in aquafeed formulations significantly affect certain ratios of diet proximate composition. Hence, it is important to accurately formulate diets when different lipid levels are supplemented in fish diets (Al-Thobaiti et al., 2017). This study used formulations with a balanced profile intended to satisfy the nutritional requirements of Petenia splendida. Diets were designed to contain different levels of lipids. There were no differences in crude protein, ether extract, crude fiber, ash, and nitrogen-free extract of experimental diets. However, calculated energy, notably increased as dietary lipid level increased. Similar results were observed by Martino et al. (2005), who found that varying levels of dietary lipid (190, 210, 230, 250 and $270 \mathrm{~g} \mathrm{~kg}^{-1}$ ) in diets for teleost carnivorous fish surubim Pseudoplatystoma coruscans, registered an increased gross energy $(21.2,21.6,22.4,22.8,23.2$ $\mathrm{MJ} \mathrm{kg}{ }^{-1}$ ) content in experimental diets. 
Table 2. Whole-body proximal composition $\left(\mathrm{g} \mathrm{kg}^{-1}\right)$ (mean \pm standard deviation) on a dry basis of Petenia splendida juveniles fed a commercial diet (as control) and four diets formulated with different lipid levels (5, 10, 15 and 20\%). Values are means from triplicate groups of fish where the letters in each row with different superscripts are significantly different $(P<0.05)$.

\begin{tabular}{lccccc}
\hline \multirow{2}{*}{ Diet } & \multicolumn{5}{c}{ Experimental groups $(\%)$} \\
\cline { 2 - 6 } & $\mathrm{C}$ & 5 & 10 & 15 & 20 \\
\hline Protein & $50.9 \pm 1.10^{\mathrm{b}}$ & $56.0 \pm 0.71^{\mathrm{a}}$ & $54.0 \pm 2.11^{\mathrm{ab}}$ & $51.9 \pm 0.41^{\mathrm{b}}$ & $53.7 \pm 1.60^{\mathrm{ab}}$ \\
Lipids & $17.4 \pm 6.81^{\mathrm{abc}}$ & $13.9 \pm 3.30^{\mathrm{bc}}$ & $20.2 \pm 3.51^{\mathrm{ab}}$ & $12.6 \pm 2.40^{\mathrm{c}}$ & $23.0 \pm 1.72^{\mathrm{a}}$ \\
Fibre & $0.1 \pm 0.10$ & $0.1 \pm 0.11$ & $0.1 \pm 0.14$ & $0.1 \pm 0.00$ & $0.1 \pm 0.01$ \\
Ash & $10.6 \pm 0.51$ & $11.6 \pm 0.50$ & $8.3 \pm 5.21$ & $10.3 \pm 0.71$ & $10.7 \pm 0.51$ \\
Nitrogen-free extract & $21.1 \pm 7.92$ & $18.8 \pm 2.91$ & $17.5 \pm 9.12$ & $25.2 \pm 2.21$ & $12.5 \pm 0.50$ \\
Gross energy (kcal g) & $5681.5 \pm 334.51$ & $5549.0 \pm 112.0$ & $5406.5 \pm 105.4$ & $5735.8 \pm 340.3$ & $5598.9 \pm 107.2$ \\
\hline
\end{tabular}

Table 3. Growth, feed, and lipid utilization and survival (mean \pm standard deviation) of Petenia splendida juveniles fed a commercial diet (as control) and four diets formulated with different lipid levels (5, 10, 15, and 20\%). Diferent superscripts letters in the same raw indicate significant differences $(P<0.05)$. WG: weight gain, FCR: feed conversion ratio, FI: feed intake, DLI: daily lipid intake, LER: lipid efficiency ratio, $\mathrm{K}$ : condition factor.

\begin{tabular}{lccccc}
\hline \multirow{2}{*}{ Indices } & \multicolumn{5}{c}{ Experimental groups } \\
\cline { 2 - 6 } & $\mathrm{CD}$ & 5 & 10 & 15 & 20 \\
\hline WG (\%) & $267.34 \pm 10.90^{\mathrm{c}}$ & $361.12 \pm 8.50^{\mathrm{b}}$ & $386.62 \pm 38.90^{\mathrm{b}}$ & $444.42 \pm 8.31^{\mathrm{a}}$ & $346.31 \pm 26.30^{\mathrm{b}}$ \\
FCR & $0.52 \pm 0.01^{\mathrm{c}}$ & $0.44 \pm 0.10^{\mathrm{b}}$ & $0.41 \pm 0.05^{\mathrm{b}}$ & $0.36 \pm 0.05^{\mathrm{a}}$ & $0.41 \pm 0.10^{\mathrm{b}}$ \\
FI $\left(\mathrm{g} \mathrm{fish}{ }^{-1}\right)$ & $0.039 \pm 0.00$ & $0.041 \pm 0.00$ & $0.040 \pm 0.00$ & $0.041 \pm 0.00$ & $0.042 \pm 0.00$ \\
DLI (g fish) & $0.006 \pm 0.00$ & $0.002 \pm 0.00$ & $0.004 \pm 0.00$ & $0.006 \pm 0.00$ & $0.008 \pm 0.00$ \\
LER & $12.10 \pm 0.20^{\mathrm{c}}$ & $45.71 \pm 5.84^{\mathrm{a}}$ & $24.80 \pm 2.60^{\mathrm{b}}$ & $18.8 \pm 2.40^{\mathrm{c}}$ & $12.4 \pm 1.92^{\mathrm{c}}$ \\
K factor & $1.20 \pm 0.00$ & $1.35 \pm 0.11$ & $1.25 \pm 0.03$ & $1.27 \pm 0.00$ & $1.23 \pm 0.01$ \\
Survival (\%) & $100.00 \pm 0.00$ & $88.90 \pm 8.41$ & $88.33 \pm 10.00$ & $84.42 \pm 5.12$ & $91.10 \pm 6.90$ \\
\hline
\end{tabular}

No significant differences in whole-body proximate composition were detected among experimental diets, except in lipid content. However, there were no significant differences between control fish and those fed experimental diets, higher $(P<0.05)$ lipid values were detected in the whole body of fish fed diets containing 10 and $20 \%$ of lipid. Similar results were found by Han et al. (2014), who observed different crude lipids deposition in juvenile giant croaker, Nivea japonica, fed diets containing different lipid levels. The wholebody lipid composition was found to be the lowest in fish fed 15\% (experimental group showing the highest growth in this study). Often, the proximate composition of the whole body will not indicate the real effects of diets in the lipid deposition in tissues (Denssen et al., 2017). In this research, lipids could be stored differentially on the liver and muscle. Fish oil content in fish diets may affect body composition and its deposition in muscle and liver. In this respect, some authors have found significant or minor differences. For example, Niu et al. (2007) and Peng et al. (2008) observed that lipid deposition in dorsal fish muscle recorded changes by the use of different kind of oils in the diet, while Huang et al. (2016) and Yu et al. (2017) observed that lipid in liver suffered changes when experimental fish was fed diets supplemented with different lipid sources. Dietary lipid sources and levels in fish diets produce several changes in lipid deposition in tissues and activities related to lipid metabolism enzymes (Kim \& Lee, 2004).

The present study showed that fish well-accepted experimental diets. Feed intake and survival were not significantly different among experimental groups. Our results agree with those found by Aliyu-Paiku et al. (2010), who observed that diets containing different lipid ratios did not compromise growth, survival, and feed intake of snakehead (Channa striatus). FCR recorded in all experimental fish was low, which can be explained by the small size of fish used in this study $(0.65 \pm 0.19 \mathrm{~g})$. Physiologically speaking, FCR change as fish gets older. For example, FCR for larvae fish is generally lower than that of the same species of fish in juvenile or adult stages (Kolkovski, 2013).

It is well known that fish oil contains fatty acids necessary to cover the nutritional requirements of any carnivorous fish (Cowey \& Sargent, 1977; Turchini et al., 2009; Kabeya et al., 2018; Wang et al., 2018) like $P$. splendida. Lipids, together with cholesterol and 
essential fatty acids provide energy and elements for building cellular membranes (Lee et al., 2002; Turchini et al., 2011; Jin et al., 2013). The importance of certain components of lipids such as n-3 highly unsaturated fatty acids, HUFA (present in fish oil), for carnivorous marine fish nutrition is evident. For carnivorous freshwater fish, HUFA requirements are lower and not essential as in marine fish because they can desaturate and elongate them (Sargent et al., 1999). The present research used 5, 10, 15, and $20 \%$ of fish oil as a lipid source to assess the optimal requirement for $P$. splendida. In this study, it was demonstrated that $P$. splendida achieved an acceptable growth when fed experimental diets, compared with previous studies using with same specie (Alvarez-González et al., 2008). Each species has different lipid level requirements to achieve desired growth. For example, Lazzari et al. (2016) demonstrated that South American catfish (Ramdhia quelen, Quoy \& Gaimard, 1824) require a $10 \%$ lipid level in the diet to promote a correct WG and FCR. Han et al. (2014) reported that Japanese croaker (Nibea japonica) needs $8.22 \%$ of lipid in the diet to maintain an acceptable growth. Lipid requirement of fish has been reported to vary with species, size or age, water quality, presence of natural food, and feeding and culture management (NRC, 1993). In diet formulation and manufacturing, it is important to an optimized nutrient requirement to obtain in a short period, maximum growth, better nutrient retention, and an improved FCR (Tocher, 2010). Inadequate lipid levels could negatively affect the growth and health of fish (Arce \& Luna, 2003; González-Félix et al., 2016). In contrast, an adequate level of lipids improves its utilization and the energetic use of other nutrients (Zhang et al., 2018), hence providing improved fish growth. This study showed that diets containing a $15 \%$ level of lipid significantly improved experimental fish growth. This result agrees with dietary lipid requirements for other cichlid species, such as Cichlasoma trimaculatum, which reported a notably high (22\%) lipid requirement. From a physiological point of view, high lipid requirement seems to be the result of the digestive enzyme activities of cichlid species (Toledo-Solís et al., 2020). In carnivorous fish, high lipid requirement has been reported. Ruey-Liang et al. (2001) observed that cobia, Rachycentron canadum, requires $18 \%$ of lipidic content. Huerta-Ortiz et al. (2009) reported that tropical gar (Atractosteus tropicus) has a lipid requirement of 15\%. Buchet et al. (2000) reported 15\% of lipid requirement for red drum (Sciaenops ocellatus). López et al. (2006) reported that between 15.5 and $18 \%$ of lipids for white seabass (Atractoscion nobilis). In comparison, other studies suggest that gilt-head sea bream (Sparus aurata) requires $26 \%$ of lipid (Moñino et al., 2002) and Atlantic cod (Gadus morhua) requires
18\% (Hansen et al., 2008). Based on the second-order polynomial regression analysis of WG, we found that $16.2 \%$ lipid provides an optimal growth of $P$. splendida. This variability, between real lipid content in diet and optimal lipid requirement derived from a second-order polynomial regression analysis, has been previously reported. Mohanta et al. (2008) observed that based on the highest energy efficiency and proper balance between dietary protein and non-protein energy content, the optimal lipid level required by silver barb Puntius gonionotus is $8 \%$. However, after further analysis by second-order polynomial regression analysis, it was found that the optimum level for this species is $9.6 \%$.

In this study, a significant decrease in growth was recorded with $20 \%$ of dietary lipid levels. Previous studies have reported that a decrease in fish growth has been observed when dietary lipid levels exceed optimal requirements (Lv et al., 2015; Chang et al., 2017; Zhang et al., 2018). Wang et al. (2012) found that WG and specific growth rate of Pseudobargrus ussuriensis fingerlings decreased with increasing dietary lipid levels at the same dietary protein level. The authors concluded that extra lipid was not used as an energy source even if the protein level was appropriate for the species. Other authors as Sveier et al. (1999) and Sargent et al. (2002), suggested an excessive level of lipid reduced growth of fish due to the inhibition of fatty acid synthesis and the reduction of fish's ability to digest and assimilate it. Furthermore, it is well known that an elevated level of lipid in diets can exceed the energetic demand interrupting nutrient intake, which is reflected in reduced growth (Aliyu-Paiku et al., 2010).

Lipid levels in the diet can affect lipid and protein content in whole-body proximate composition (Bolasina \& Fenucci, 2007). Our study demonstrated that $P$. splendida showed different lipid deposition in the whole body with increasing levels of diet. Similar results were found by Han et al. (2014), who found that $N$. japonica increased lipid deposition in whole body and muscle as lipid level increased in diets with different lipid levels $(5,9,13$ and 17\%). Other authors have concluded that high lipid levels in the diet can produce fatty fish farmed in controlled systems (Tan et al., 2019; Xu et al., 2019). In this study, 20\% lipid level in diets for juveniles of $P$. splendida presented the highest percentage of lipids in the whole body, which can be explained by the deposition of lipids in the form of mesenteric fat. Similar results were found by Denssen et al. (2017), who observed an increased visceral mass and lipid levels in the whole-body proximate composition indicating a lipostatic regulation. Dietary lipids deposition is mainly carried out in both muscle and viscera, which are the major deposition sites of fats in fish, accounting for $60-65 \%$ 
of body mass (Jobling et al., 2002). Excessive dietary lipids may lead to increased catabolism of the dietary nutrients compromising nutrient retention efficiency (Refstie et al., 2001) as demonstrated in this study where LER resulted significantly lower in fish fed 20 and $15 \%$ compared to those shown in fish fed 5 and $10 \%$ experimental diets.

Similarly, a lower protein and lipid levels in fish whole body fed $15 \%$ diet was observed, compared to those found in the whole body of experimental groups fed diets containing a lower, 5, and 10\% lipid level. Variability of protein and lipid in fish carcass fed different levels of lipids in the diet is well documented. Guo et al. (2019) recorded different body protein levels in largemouth bass Micropterus salmoides fed five lipid levels (3.3, 8.2, 13.2, 18.1 and 23.3\%). Similarly, Bolasina \& Fenucci (2007), observed that Brazilian codling (Urophycis brasiliensis, Kaup, 1858) fed with a low level of dietary lipid (3\%) showed $14.92 \%$ crude lipid and $80 \%$ of crude protein in muscle while fish fed with a higher level of dietary lipid (10\%) recorded $16.43 \%$ crude lipid and $76.02 \%$ of crude protein in muscle.

\section{CONCLUSIONS}

In conclusion, this research suggests that Petenia splendida can grow properly with dietary levels of lipids ranging from 5 to $20 \%$, being the optimal $15 \%$. However, according to the second-order polynomial regression analysis of WG, $16.2 \%$ resulted in the optimal required for this species. Furthermore, it is concluded that a higher lipid level $(20 \%)$ in $P$. splendida diets resulted in the growth reduction of fish.

\section{ACKNOWLEDGMENTS}

The authors would like to thank the CatedrasCONACYT Program through the "Enhancement of digestive physiology and aquaculture nutrition" research project. We are also grateful for the economic support of CONACYT. -Through the project, Tabasco State Government: "Ingredient identification in formulated feeds and its digestibility in the experimental culture of native species" and to the United States Agency for International Development (USAID) for financial support to this research.

\section{REFERENCES}

Abdo de la Parra, M.I., Rodríguez-Ibarra, L.E., Rodríguez-Montes de Oca, G., Velasco-Blanco, G. \& Ibarra-Casto, L. 2015. Estado actual del cultivo de larvas del pargo flamenco (Lutjanus guttatus). Latin
American Journal of Aquatic Research, 43(3): 415-423. doi: 10.3856/vol43-issue3-fulltext-3

Abdo de la Parra, M.I., Rodríguez-Ibarra, L.E., Hernández, C., Hernández, K., González-Rodríguez, B., Martínez-Rodríguez, I. \& García-Ortega A. 2010. Efecto de diferentes niveles de proteína y lípidos totales en la dieta sobre el crecimiento y supervivencia de juveniles de pargo lunarejo Lutjanus guttatus. Revista de Biología Marina y Oceanografía, 45(3): 433-439. doi: 10.4067/S0718-19572010000300008

Ahmed, N. \& Thompson, S. 2019. The blue dimensions of aquaculture: a global synthesis. Science of the Total Environment, 652: 851-861. doi: 10.1016/j.scitotenv. 2018. 10.163

Aliyu-Paiku, M., Hashim, R. \& Shu-Chien, A.C. 2010. Influence of dietary lipid/protein ratio on survival, growth, doby indices, and digestive lipase activity in Snakehead (Channa striatus Bloch, 1793) fry reared in the recirculating water system. Aquaculture Nutrition, 16(5): 466-474. doi: 10.1111/j.1365-2095.2009.006 83.x

Al-Thobaiti, A., Al-Ghanim, K., Suliman, E.M. \& Mahboob, S. 2017. Impact of replacing fish meal by a mixture of different plant protein sources on the growth performance of Nile tilapia (Oreochromis niloticus L.) diets. Brazilian Journal of Biology, 78(3): 525-534. doi: 10.1590/1519-6984.172230

Alvarez-González, C.A., Márquez-Couturier, G., AriasRodríguez, L., Contreras-Sánchez, W.M., UscangaMartínez, A., Perales-García, N., et al. 2008. Avances en la fisiología digestiva y nutrición de la mojarra tenguayaca Petenia splendida. In: Cruz-Suárez, E., Ricque-Marie, D., Tapia-Salazar, M., Nieto-López, M.G., David, A., Villarreal-Cavazos, D.A., Lazo, J.P. \& Viana, M.T. (Eds.). Avances en nutrición acuícola. IX Simposio Internacional de Nutrición Acuícola, Noviembre 24 - 27, Universidad Autónoma de Nuevo León, Nuevo León, pp. 135-235.

Anderson, J.L., Asche, F. \& Garlock, T. 2018. Global and commodication: the transformation of the seafood market. Journal of Commodity Markets, 12: 2-8. doi: 10.1016/ j.jcomm. 2017.12.004

Analysis of the Association of Official Analytical Chemistry (AOAC). 1995. Official methods of analysis of the Association of Official Analytical Chemistry. AOAC, Washington, DC.

Arce, U.E. \& Luna, F.J. 2003. Efecto de dieta con diferente contenido proteico en las tasas de crecimiento de crías del bagre del Balsas Ictalurus balsanus (Pisces: Ictaluridae) en condiciones de cautiverio. Revista AquaTIC, 18: 39-47.

Ayisi, C.L., Yamei, C. \& Zhao, J-L. 2018. Genes, transcription factors, and enzymes involved in lipid 
metabolism in finfish. Agri Gene, 7: 7-14. doi: 10.1016/j.aggene.2017.09.006

Bolasina, S.N. \& Fenucci, J.L. 2007. Effects of dietary lipid level on growth, survival, and body composition of Brazilian codling (Urophycis brasiliensis Kaup, 1858). Revista de Biología Marina y Oceanografía, 42(1): 23-27. doi: 10.4067/S0718-195720070001000 03

Brander, K., Cochrane, K., Barange, M. \& Soto, D. 2017. Climate change implications for fisheries and aquaculture. In: Phillips, B.F. \& Pérez-Ramírez, M. (Eds.). Climate changes impacts in fisheries and aquaculture: a global analysis. John Wiley \& Sons, New Jersey, pp. 45-62. doi: 10.1002/9781119154 051.ch3

Buchet, V., Zambonino-Infante, J.L. \& Cahu, C.L. 2000. Effect of lipid level in a compound diet on the development of red drum Sciaenops ocellatus larvae. Aquaculture, 184(3-4): 339-347. doi: 10.1016/S00448486(99)00325-7

Bush, S.R., Belton, B., Little, D.C. \& Saidul-Islam, M. 2019. Emerging trends in aquaculture value chain. Aquaculture, 498: 428-434. doi: 10.1016/j.aquaculture.2018.08.077

Castillo-Torres, P.A., Martínez-Meyer, E., CórdovaTapia, F. \& Zambrano, L. 2017. Potential distribution of native freshwater fish in Tabasco, México. Revista Mexicana de Biodiversidad, 88(2): 415-424. doi: 10.1016/j.rmb.2017. 03.001

Chang, J., Niu, H.X., Jia, Y.D., Li, S.G. \& Xu, G.F. 2017. Effects of dietary lipid levels on growth, feed utilization, digestive tract enzyme activity and lipid deposition of juvenile Manmchurian trout, Brachymystax lenok (Pallas). Aquaculture Nutrition, 24(2): 694-701. doi: 10.1111 /anu. 12598

Chávez de Martínez, M.C. 1990. Vitamin C requirement of the Mexican native cichlid Cichlasoma urophthalmus (Gunther). Aquaculture, 86(4): 409-416. doi: 10.1016/0044-8486(90) 90329-L

Chávez-López, R., Peterson, M.S., Brown-Peterson, N.J., Morales-Gómez, A.A. \& Franco, J. 2005. Ecology of the mayan cichlid, Cichlasoma urophthalmus Günther, in the Alvarado Lagoonal System, Veracruz, Mexico. Gulf and Caribbean Research, 17(1): 123-131. doi: $10.18785 /$ gcr. 1701.13

Cowey, C.B. \& Sargent, J.R. 1977. Lipid nutrition in fish. Comparative Biochemistry and Physiology Part B: Compa-rative Biochemistry, 57(4): 269-273. doi: 10.1016/0305-0491(77)90051-7

Dávila-Camacho, C.L., Galaviz-Villa, I., Lango-Reynoso, F., Castañeda-Chávez, R., Quiroga-Brahms, C. \& Montoya-Mendoza, J. 2018. Cultivation of native fish in Mexico: cases of success. Reviews in Aquaculture, 11(3): 1-14. doi: 10.1111/raq.12259
Denssen, J-E., Weihe, R., Hatlen, B., Thomassen, M.S. \& Rovik, K-A. 2017. Different growth performance, lipid deposition, and nutrient utilization in in-season (S1) Atlantic salmon post-smolt fed isoenergetic diets differing in protein-to-lipid ratio. Aquaculture, 473: 345-354. aquacuaculture doi: 10.1016/j.aquaculture. 2017.02.006

Devezé-Murillo, P., Reta-Mendiola, J.L. \& SánchezLuna, B. 2004. Cultivo de Poecilia reticulata (Pisces: Poecilidae) en cuerpos de agua tropicales, Veracruz, Mexico. Revista de Biología Tropical, 52(4).

Goldburg, R. \& Naylor, R. 2005. Future seascapes, fishing, and fish farming. Frontiers in Ecology and Environment, 3(1): 21-28. doi: 10.1890/1540-9295 (2005)003[0021:FSFAFF]2.0.CO;2

González-Félix, M.L., Maldonado-Othón, C.A. \& PérezVelázquez, M. 2016. Effect of dietary lipid level and replacement of fish oil by soybean oil in compound feeds for the shortfin corvina (Cynoscion parvipinnis). Aquaculture, 454: 217-228. doi: 10.1016/j.aquaculture. 2015.12.021

Guo, J-L., Zhou, Y-L., Zhao, H., Chen, W-Y., Chen, Y-J. \& Lin, S-M. 2019. Effect of dietary lipid level in growth, lipid metabolism and oxidative status of largemouth bass, Micropterus salmoides. Aquaculture, 506: 394-400. doi: 10.1016/j.aquaculture.2019.04.007

Han, T., Li, X., Wang, J., Hu, S., Jiang, Y. \& Zhong, X. 2014. Effect of dietary lipid level on growth, feed utilization, and body composition of juvenile giant croaker Nibea japonica. Aquaculture, 434: 145-150. doi: 10.1016/j.aquaculture.2014.08.012

Hansen, J.O., Berge, G.M., Hillestad, M., Krogdahl, A., Galloway, T.F., Holm, H., Holm, J. \& Ruyter, B. 2008. Apparent digestion and apparent retention of lipid and fatty acids in Atlantic cod (Gadus morhua) fed increasing dietary lipid levels. Aquaculture, 284(1-4): 159-166. doi: 10.1016/j.aquaculture.2008.07.043

Hernández, M., Gasca-Leyva, E. \& Milstein, A. 2014. Polyculture of mixed-sex and male populations of Nile tilapia (Oreochromis niloticus) with the Mayan cichlid (Cichlasoma urophthalmus). Aquaculture, 418-419: 26-31. doi: 10.1016/j.aquaculture.2013.09.035

Hua, K., Koppe, W. \& Fontanillas, R. 2019. Effets of dietary protein and lipid levels on growth, body composition, and nutrient utilization of Channa striata. Aquaculture, 501: 368-373. doi: 10.1016/j. aquaculture.2018.11.054

Huang, Y.S., Wen, X.B., Li, S.K., Li, W.J. \& Zhu, D.S. 2016. Effects of dietary fish oil replacement with palm oil on the growth, feed utilization, biochemical composition, and antioxidant status of juvenile Chu's croaker, Nivea coibor. Journal of the World Aquaculture Society, 47(6): 786-797. doi: 10.1111/ jwas. 12307 
Huerta-Ortiz, M., Alvarez-González, C.A., MárquezCouturier, G., Contreras-Sánchez, W.M., CiveraCerecedo, R. \& Goytortua-Bores, E. 2009. Sustitución de aceite de pescado con aceite vegetal en larvas de pejelagarto Atractosteus tropicus. Kuxulkab, 15(28): 51-52.

Hulsey, C.D., García de León, J., Sánchez-Johnson, Y., Hendrickson, D.A. \& Near, T.J. 2004. Temporal diversification of Mesoamerican cichlid fishes across a major biogeographic boundary. Molecular Phylogenetics and Evolution, 31(2): 754-764. doi: 10.1016/j.ympev. 2003.08.024

Instituto Nacional de Pesca. 2019. Acuacultura Tenguayaca. Especies con potencial acuícola. [https:// www.gob.mx/inapesca/acciones-y-programas/acuacultura-tenguayaca? tab=]. Reviewed: August 9, 2019.

Jiménez-Martínez, L.D., Alvarez-González, C.A., Contreras-Sánchez, W.M., Márquez-Couturier, G. \& Almeida-Madrigal, J.A. 2009. Evaluation of larval growth and survival in Mexican mojarra, Cichlasoma urophthalmus and bay snook, Petenia splendida under different initial stocking densities. Journal of the World Aquaculture Society, 40(6): 753-761. doi: 10.1111/j.1749-7345.2009.00295.x

Jin, Y., Li-Xia, T., Shuai-lin, Z., Shi-Wei, X., Hui-Jun, Y., Gui-Ying, L. \& Yong-Jian, L. 2013. Dietary lipid requirement on non-specific immune responses in juvenile grass carp (Ctenopharyngodon idella). Fish \& Shellfish Immunology, 34(5): 1202-1208. doi: 10.1016/j.fsi.2013.01.008

Jobling, M., Andreassen, B., Larsen, A.V. \& Olsen, R.L. 2002. Fat dynamics of Atlantic salmon Salmo salar L. smolt during early seawater growth. Aquaculture Research, 33(10): 739-745. doi: 10.1046/j.13652109.2002.00712.x

Kabeya, N., Yevzelman, S., Oboh, A., Tocher, D.R. \& Monroig, O. 2018. Essential fatty acids metabolism and requirements of the cleaner fish, ballan wrasse Labrus bergylta: defining pathways of long-chain polyunsaturated fatty acid biosynthesis. Aquaculture, 488: 199-206. doi: 10.1016/j.aquaculture.2018.01.039

Kim, K. \& Lee, S. 2004. Requirement of dietary n-3 highly unsaturated fatty acids on growth, body composition, and blood chemistry of juvenile starry flounder (Patichthys stellatus). Aquaculture, 229: 315323. doi: 10.1016/S0044-8486(03)00356-9

Kim, K., Park, Y., Je, H.W., Seong, M., Damusaru, J.H., Kim, S., Jung, J.Y. \& Bai, S.C. 2019. Tuna byproducts as fishmeal in tilapia aquaculture. Ecotoxicology and Environmental Safety, 172: 364-372. doi: 10.1016/j.ecoenv.2019.01.107

Kolkovski, S. 2013. Microdiets as alternatives to live feeds for larvae in aquaculture: improving the efficiency of feed particle utilization. In: Allan, G. \& Burnell, G. (Eds.). Advances in aquaculture hatchery technology. Woodhead Publishing, Cambridge, pp. 203-222.

Lazzari, R., Emanuelli, T., Maschio, D., Ferreira, C.C., Battisti, E.K. \& Radünz-Neto, J. 2016. The inclusion of soybean oil in the diets of silver catfish (Rhamdia quelen) in relation to growth quality and fillet acceptability. Latin American Journal of Aquatic Research, 44(1): 39-45.

Lee, S.M., Jeon, I.G. \& Lee, J.Y. 2002. Effects of digestible protein and lipid levels in practical diets on growth, protein utilization and body composition of juvenile rockfish Sebastes schlegelii. Aquaculture, 211(1-4): 227-239. doi: 10.1016/S0044-8486(01)008 80-8

López, L.M., Torres, A.L., Durazo, E., Drawbridge, M. \& Bureau, D.P. 2006. Effect of lipid on growth and feed utilization of white seabass (Atractoscion nobilis) fingerlings. Aquaculture, 253(1-4): 557-563. doi: 10.1016/j.aquaculture.2005.08.007

Lv, Y., Chang, Q., Chen, S., Yu, C., Qin, B. \& Wang, Z. 2015. Effect of dietary protein and lipid levels on growth and body composition of spotted halibut, Verasper variegatus. Journal of the World Aquaculture Society, 46(3): 311-318. doi: 10.1111/jwas. 12196

Martino, R.C., Cyrino, J.E.P., Portz, L. \& Trugo, L.C. 2005. Performance, carcass composition and nutrient utilization of surubim Pseudoplatystoma coruscans (Agassiz) fed diets with varying carbohydrate and lipid levels. Aquaculture Nutrition, 11(2): 131-137. doi: 10.1111/j.1365-2095.2004.00332.x

Méndez, A., García, M.E. \& Lozano, L. 2011. Sistemática del pez Petenia splendida (Perciformes: Cichlidae) en el lago Petén Tizá, Guatemala. Revista de Biología Tropical, 59(3): 1205-1216.

Mohanta, K.N., Mohanty, S.N., Jena, J.K. \& Sahu, N.P. 2008. Optimal dietary level of silver barb, Puntius gonionotus fingerlings in relation to growth, nutrient retention and digestibility, muscle nucleic acid content and digestive enzyme activity. Aquaculture Nutrition, 14(4): 350-359. doi: 10.1111/j.1365-2095.2007.00 542. $\mathrm{x}$

Montoya-Martínez, C., Nolasco-Soria, H., Carillo-Farnés, O., Civera-Cerecedo, R., Álvarez-González, C. \& Vega-Villasante, F. 2016. Chemical score of different protein sources to four Macrobrachium species. Latin American Journal of Aquaculture Research, 44(4): 835-844. doi: 10.3856/vol44-issue4-fulltext-19

Moñino, A., Tomás, A., Fernández, M., Lázaro, R., Pérez, L., Espinosa, F.J., Tiana, A. \& Jover, M. 2002. Estudio del crecimiento, aprovechamiento nutritivo y de la productividad económica de la dorada Sparus aurata L., 1758 alimentada con piensos comerciales de diferente contenido en proteína y lípidos. Boletín. Instituto Español de Oceanografía, 18(1-4): 275-280. 
Morales, A.E., Cardenete, G., De la Higuera, M. \& Sanz, A. 1994. Effects of dietary protein source on growth, feed conversion and energy utilization in rainbow trout, Oncorhynchus mykiss. Aquaculture, 124(1-4): 117-126. doi: 10.1016/0044-8486(94)90367-0

Niu, J., Liu, Y.J., Tian, L.X., Mai, K.S., Zhou, Q.C., Yang, H.J. \& Ye, C.X. 2007. Maize oil can replace fish oil in the diet of grouper postlarvae (Epinephelus coioides) without adversely affecting growth or fatty acid composition. American Journal of Agriculture and Biological Sciences, 2(2): 81-87.

National Research Council (NRC). 1993. Nutrient requirement of fish. National Academy Press, Washington, DC.

Olaussen, J.O. 2018. Environmental problems and regulation in the aquaculture industry. Insight from Norway. Marine Policy, 98: 158-163. doi: 10.1016/ j.marpol.2018.08.005

Peng, S.M., Cheng, L.Q., Qin, J.G., Hou, J.L., Yu, N., Long, C.Q., Ye, J.Y. \& Sun, X.J. 2008. Effects of replacement of dietary fish oil by soybean oil on growth performance and liver biochemical composition in juvenile black sea bream, Acanthopagrus schlegeli. Aquaculture, 276: 154-161. doi: 10.1016/ j.aquaculture.2008.01.035

Perez-Sánchez \& Páramo-Delgadillo, S. 2008. The culture of cichlids of southeastern Mexico. Aquaculture Research, 39(7): 777-783. doi: 10.1111/j.1365-2109. 2008.01929.x

Refstie, S., Storebakken, T., Baeverfjord, G. \& Roem, A.J. 2001. Long-term protein and lipid growth of Atlantic salmon (Salmo salar) fed diets with partial replacement of fish meal by soy protein products at medium or high lipid level. Aquaculture, 193(1-2): 91106. doi: 10.1016/S0044-8486(00)00473-7

Rombenso, A.N., Trushenski, J.T. \& Schwarz, M.H. 2016. Fish oil replacement in feeds for juvenile Florida pompano: composition of alternative lipid influences degree of tissue fatty acid profile distortion. Aquaculture, 458: 177-186. doi: 10.1016/j.aquaculture. 2016.03.009

Ross, L.G. \& Beveridge, M.C.M. 1995. Is a better strategy necessary for development of native species for aquaculture? A Mexican case study. Aquaculture Research, 26(8): 539-547. doi: 10.1111/j.1365-2109. 1995.tb00944.x

Ruey-Liang, C., Mao-Sen, S. \& Houng-Yung, C. 2001. Optimal dietary protein and lipid levels for juvenile cobia Rachycentron canadum. Aquaculture, 193(1-2): 81-89. doi: 10.1016/S0044-8486(00)00480-4

Sales, J. \& Janssens, G.P.J. 2003. Nutrient requirements of ornamental fish. Aquatic Living Resources, 16(3): 533-540. doi: 10.1016/j.aquliv.2003.06.001
Sargent, J., McEvoy, L., Estevez, A., Bell, G., Bell, M., Henderson, J. \& Tocher, D. 1999. Lipid nutrition of marine fish during early development: current status and future directions. Aquaculture, 179(1-4): 217-229. doi: 10.1016/S0044-8486(99)00191-X

Sargent, J.R., Tocher, D.R. \& Bell, J.G. 2002. The lipids. In: Halver J.E. \& Hardy, R.W. (Eds.). Fish nutrition. Academic Press, London, pp. 182-257.

Sveier, H., Wahtne, H. \& Lied, E. 1999. Growth, feed and nutrient utilization and gastrointestinal evacuation time in Atlantic salmon (Salmo salar L.): the effect of dietary fish meal particle size and protein concentration. Aquaculture, 180(3-4): 265-282. doi: 10.1016/S0044-8486(99)00196-9

Shariff, M. 2007. Impact of diseases on aquaculture in the Asia-Pacific region as exemplified by epizootic ulcerative syndrome (EUS). Journal of Applied Ichthyology, 14(3-4): 139-144. doi: 10.1111/j.14390426.1998.tb00631.X

Tacon, A.G.J. \& Forster, I.P. 2003. Aquafeeds and the environment: policy implications. Aquaculture, 226(14): 181-189. doi: 10.1016/S0044-8486(03)00476-9

Tan, X., Sun, Z. \& Ye, C. 2019. Dietary Lycium barbarum extract administration improved growth, meat quality and lipid metabolism in hybrid grouper (Epinephelus lanceolatus $\widehat{\delta} \times$ E. fuscoguttatus +) fed high lipid diets. Aquaculture, 504: 190-198. doi: 10.1016/j.aquaculture.2019.01.044

Tocher, D.R. 2010. Metabolism and functions of lipids and fatty acids in teleost fish. Reviews in Fishery Science, 11(2): 107-184. doi: 10.1080/713610925

Toledo-Solís, F.J., Martinez-Garcia, R., Galaviz M.A., Hilerio-Ruiz, A.G., Alvarez-González, C.A. \& Sáenz de Rodrigáñez, M. 2020. Protein and lipid requirements of three-spot cichlid Cichlasoma trimaculatum larvae. Fish Phyiology and Biochemistry, 46(1): 23-37. doi: 10.1007/s10695-01900692-9

Trejo-Escamilla, I., Galaviz, M.A., Flores-Ibarra, M., Álvarez-González, C.A. \& López, L.M. 2016. Replacement of fishmeal by soya protein concentrate in the diets of Totoaba macdonaldi (Gilbert, 1890) juveniles: effects on the growth performance, in vitro digestibility, digestive enzymes and the haematological and biochemistry parameters. Aquaculture Research, 48(8): 4038-4057. doi: 10.1111/are.13225

Turchini, G.M., Tortensen, B.E. \& Ng, W.K. 2009. Fish oil replacement on finfish nutrition. Reviews in Aquaculture, 1: 10-57. doi: 10.1111/j.1753-5131. 2008.01001.x

Turchini, G.M., Francis, D.S., Senadheera, S.P.S.D., Thanuthong, T. \& De Silva, S.S. 2011. Fish oil 
replacement with different vegetable oils in Murray cod: evidence of an "omega-3 sparing effect" by other dietary fatty acids. Aquaculture, 315(3-4): 250-259. doi: 10.1016/j.aquaculture.2011.02.016

Uscanga-Martínez, A., Alvarez-González, C.A., Contreras-Sánchez, W.M., Márquez-Couturier, G., Civera-Cerecedo, R., Nolasco-Soria, H., et al. 2012. Protein requirement in masculinized and nonmasculinized juveniles of Bay Snook. Hidrobiológica, 22(3): 219-228.

Vidal-López, J.M., Alvarez-González, C.A., ContrerasSánchez, W.M. \& Hernández-Vidal, U. 2009. Masculinización del cíclido native Tenguayaca, Petenia splendida (Günther, 1862), usando nauplios de Artemia como vehículo del esteroide 17- $\alpha$ metiltestosterona. Hidrobiológica, 19(3): 211-216.

Wang, J., Han, S.L., Li, L.Y., Lu, D.L., Limbu, S.M., Li, D.L., Zhang, M.L. \& Du, Z.Y. 2018. Lipophagy is essential for lipid metabolism in fish. Science Bulletin, 63(14): 879-882. doi: 10.1016/j.scib.2018.05.026

Received: 10 September 2019; Accepted: 28 May 2020
Wang, Y.Y., Ma, G.J., Shi, Y., Liu, D.S., Guo, J.X., Yang, Y.H. \& Chen, C.D. 2012. Effects of dietary protein and lipid levels on growth, feed utilization, and body composition in Pseudobagrus ussuriensis fingerlings. Aquaculture Nutrition, 19(3): 390-398. doi: 10.1111/ j.1365-2095.2012.00972.x

Xu, H., Liao, Z., Zhang, Q., Wei, Y. \& Liang, M. 2019. A moderately high level of dietary lipid inhibited the protein secretion function of liver in juvenile tiger puffer Takifugu rubripes. Aquaculture, 498: 17-27. doi: 10.1016/j.aquaculture.2018.08.033

Yu, D.H., Chang, J.Z., Dong, G.F. \& Liu, J. 2017. Replacement of fish oil with soybean oil in diets for juvenile Chinese sucker (Myxocyprinus asiaticus): effects on liver lipid peroxidation and biochemical composition. Fish Physiology and Biochemistry, 43: 1413-1420. doi: 10.1007/s10695-017-0381-0

Zhang, J., Zhao, N., Sharawy, Z., Li, Y., Ma, J. \& Lou, Y. 2018. Effects of dietary lipid and protein level on growth and physiological metabolism of Pelteobagrus fulvidraco larvae under recirculating aquaculture system (RAS). Aquaculture, 495: 458-464. doi: 10.1016/j.aquaculture.2018.06.004 